\title{
Women Stereotypes Depicted in Daya's Song Entitled Sit Still, Look Pretty
}

\author{
A P Bahr ${ }^{1}$, F Pujiyanti ${ }^{2}$ \\ Faculty of Cultural Studies, Universitas Brawijaya, Malang, Indonesia \\ \{afraparamitabahr@gmail.com ${ }^{1}$, fariska.ub@gmail.com ${ }^{2}$ \}
}

\begin{abstract}
Binary opposition is the pairing of connected words which has antipodal meaning and hierarchical relation, for example: men and women. Since long time ago, patriarchal society had placed men in a higher position than women. This condition privileges men while handicaps women. Therefore, feminism helps women to uplift their position to be equal with men. Feminist's activism can be done through many ways, one of which is via literary works. The objective of this research is to examine women stereotype issues depicted in a feminist literary work entitled Sit Still, Look Pretty sung by Daya. To conduct this research the writers applied feminist literary criticism. The data are gained from two sources, the lyrics are taken from Genius.com and the music video is taken from Daya's official Youtube. The results reveal that Sit Still, Look Pretty both represents women stereotypes that exist in society and endorses new stereotypes of women.
\end{abstract}

Keywords: Sit Still, Look Pretty, Feminism, Women Stereotypes, Patriarchy.

\section{INTRODUCTION}

Binary opposition definitely exists in our life but it is invisible to see because it is merely a concept: it is a pair of connected words -or terms- which has antipodal meaning. [1] "Where terms are paired, the pairing is rarely symmetrical but rather hierarchical." A pair of binary opposition model in patriarchal society -man and woman- also has hierarchical relation. History had explained that women had experienced the difficulties of being the Other, the deviance of men. As Beauvoir argued that, [2] "She [woman] is defined and differentiated with reference to man, not he with reference to her; ... He is the Subject; he is the Absolute she is the Other." Not only being labelled as the second sex, subordinate, nor deviance, women also encountered some biased treatments in politics, social, and economics sector. These stories and experiences are perpetuated within feminist literary works as a criticism toward gender inequalities.

Four male songwriters that are Gino Barletta; Mike Campbell; Britten Newbill; and Scott Brezenak wrap up women experiences into one beautiful but powerful lyrics named Sit Still, Look Pretty, sung by Daya, the Indian-American singer-songwriter whose birth-name is Grace Martin Tandon. Released on March 2016, this song primarily talks about women empowerment and women stereotype issues that later will be discussed in this research. The writers decided to conduct a research under this topic due to some issues in feminism field that are appealing to be discussed, some questions have not been answered, some problem have not been resolved yet. Some people may say that women had achieved equal rights, but others 
claim that the issues of women is a never-ending story that always develops and changes over times. Therefore, further discussions in this field are necessary to conduct to enhance more knowledge in feminism field.

\section{RESEARCH METHOD}

This research uses feminist literary criticism that includes some theories which are patriar-chal system, feminism, women's oppression and also stereotype. [3] "Feminist literary criticism (also known as feminist criticism) is literary analysis that arises from the viewpoint of feminism, feminist theory and/or feminist politics." To conduct this research, some steps are needed to be followed sequentially. The first is choosing the object. The writers chose women empowerment song entitled Sit Still, Look Pretty sung by Daya due to its concern about women's stereotypes issue. The second step is collecting the data. The data were gained from 2 sources i.e. The lyrics of the song taken from Genius.com, the music video downloaded from Daya's official Youtube account. The third is analyzing and interpreting the data, in which the writers broke down and classified the lyrics of the song. After that, some related theories mentioned above are applied. The last step is making conclusion where the writers reviewed the important points of the fin-dings and drew a conclusion from it.

\section{RESULT AND DISCUSSION}

\subsection{Sit Still, Look Pretty as a Women Empowerment Song}

[4] "Long before the riot grrrl movement (parts of third-wave feminism) and power pop jams braced the music scenes, it was rather novel and even controversial to sing about gender equalities." However, today is different, time has changed. Women's empowerment has became one of some attractive themes featured within contemporary feminist song. Each feminist song certainly has different aim, concern and standpoint. As a new women empowerment song, Sit Still, Look Pretty has 2 intention: First, empowering women to take full authority over their life. Second, empowering women to dismiss their negative stereotypes as listed below.

\subsection{The Representation of Women Stereotypes in Society}

Women are Responsible for Domestic Works. The first stereotype that the writers discovered is the residual effect of patriarchal system. Indeed, we have been familiar with the traditional working division occurs in patriarchal society, where men are expected to work outside while women stays at home. This 1950s-style stereotype is surprisingly still remaining until nowadays. As reported that [5] "The literature on the division of labour has grown extensively since 1970s and the results are consistent: Women do more on housework and childcare than men." Even though women have got the rights to enter workplaces that formerly only dominated by men, yet, they are still the ones who are very responsible for housework, childcare and suchlike. Responding to this condition, Sit Still, Look Pretty invites women to reverse the patriarchal system -that by feminists women are considered taking more burden than men- via this stanza:

${ }^{6}$ Then Snow White

She did it right 


\author{
In her life \\ Had seven men to do the chores \\ 'Cause that's not what a lady's for \\ (Sit Still, Look Pretty, 2016, sixth stanza)
}

Through this stanza, the songwriters propose the idea that women should not be burdened with chores or housework. We probably have been familiar with the old fairy tale entitled Snow White and the Seven Dwarfs from which we can perceive traditional working division. This song uses irony by saying that Snow White did it right because she had seven men to do the chores, while actually she did not had that seven men to help her. Sit Still, Look Pretty also represents the fact that most of young people nowadays no longer embrace misogynistic thinking, [6] "In 2012, support for a traditional divisions of labour is much more pronounced among older peoples and least popular among the youngest age groups." The second wave feminist may believe that women should also took part in public spheres like men to support family's life. Yet, they lack of something that later is being upgraded on the third wave. [7] "Like Wollstonecraft, Taylor, and Mill before her, Friedan (in The Feminine Mystique book) sent women out into the public realm without summoning men into the private domain to pick up their fair shares of the slack." Thus, the reversal of traditional working division found in this song is like an endorsement towards the upgraded version of feminist's activism, that women's assimilation into public realm should be paired with the mutual assimilation of men into domestic spheres, or women will always be the ones taking more burden than men [7].

Women are not able to Dream High. The dealing that women stay at home while her husband work outside the house to earn living made women's chance to succeed in career were very im-possible. Until the feminists movements helped women to exit from that circumstances, and women began to enter workplaces even though it was still limited. [6] "From the mid-1990s, full-time employment for both women and men continued to grow steadily and the gap between men and women's employment is narrowing." Women's opportunities in careers keep growing as day by day. We can look at a glance that nowadays most of women have achieved equalities. However, it does not mean that the oppression against women fully disappear, it is still remaining. People may not directly say that women cannot complete high achievement in her life, but the feminists believe that people unconsciously limit women's spaces, e.g. some employers choose to hire men than women because they believe that women are often being distracted to her family responsibilities and can affect her performances. This kind of discrimination over working-women is still happening todays as criticized by the 4th stanza:

${ }^{4} \mathrm{Oh}$, I don't know what you've been told

But this gal right here's gonna rule the world

(Sit Still, Look Pretty, 2016, fourth stanza, first and second lines)

The first line can be interpreted that we actually do not know the origin of women stereotypes, what makes the stereotype becomes highly attached to women. We only know that it already spreads around society. The second line represents the way to remove the stereotypes, we have to stop showing that we are -as a woman-identical to what people believe as the typical women. Those lines also can be interpreted that even there are lots of stereotype against women, she does not need to be affected by that label. Women still can pursue her dreams (since rule the world signifies dream or goal in life) even though there are 
many stereotypes in society that imply they are not capable. In sum, Sit Still, Look Pretty's attempts to break women's stereotypes are by convincing that women do not fit the labels which society pointed to them.

Women Should Follow the Standards of Beauty. It is best-known that women are high-ly connected to makeup and dress up. Some women simply feel enough by applying powder over their face, some of them cannot go without using stunning lipstick, some admit that they are not confident without fake eyebrows and some feel best wearing thick eyelashes. There is nothing wrong with being feminine. However, the problem is: the media defines the idea of beauty under particular criteria, "Research has indicated that women in advertisements tend to be young, thin, and white," [8]. These criteria seems alike with Barbie's features. Rogers (2009, p. 29, 39, 70) mentioned that Barbie as always young, has a slim waist, and wellknown for her fair skin [9].

\author{
${ }^{1}$ Could dress up \\ To get love \\ But guess what? \\ I'm never gonna be that girl \\ Who's living in a Barbie world \\ (Sit Still, Look Pretty, 2016, first stanza)
}

Barbie as a western's beauty icon is fairly mentioned in that lyrics to represent that some people still address Barbie as their references to the standards of beauty. [10] "I don't wanna take a hit at Barbie or anything like that but I feel like there is some unrealistic beauty standards there and I personally don't believe in that." Some people say that Barbie's physical appearances are unrealistic perfection that are impossible to be achieved, but like it or not, this standard subtly shapes our perspectives towards beauty. Therefore, some women are willing to do diet to get thin-shaped body or even surgery to shape their pointed-nose merely to fit the standard, a mere beauty stereotypes created by beauty industries to sell products. Besides, Sit Still, Look Pretty also points out current body standards in the picture below:

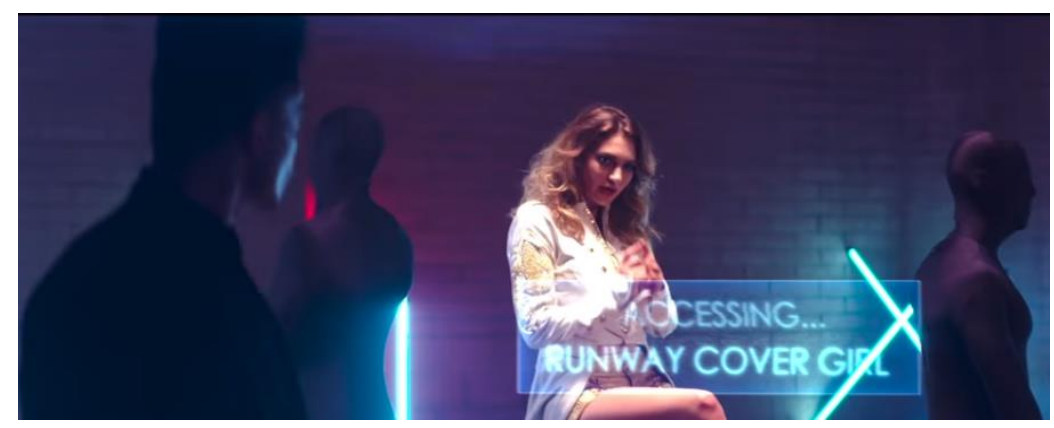

Figure 1. Daya is turned into a runway cover girl

Runway cover girls are the icon of current body and beauty standards. [11] "In the 1960s and 70s (in the US), beauty ideals for women shifted from the mature curvaceous body of stars such as Marilyn Monroe to the stick-thin and flat-chested figure epitomized by supermodels such as Twiggy or Kate Moss.” In this modern era, this beauty and body standard still 
encircles women's world. [12] "Women are under many pressures to conform to beauty ideals, and the report shows that social media is presen ting a new challenge and adding pressure to look a certain way. The findings are certainly a call for action." Endorsing \#yourbeautyrules campaign that point out every women have diverse notion of beauty to be shown to the world can help.

Women Dress Up to Get Love. [13] "Men judge women in real life based on what they see in advertisements, the unrealistic photoshopped images." Due to this, some women think that men will be impressed by their appearances if they suit the standards of beauty manifested within commercials as in these stanzas:

\author{
${ }^{1}$ Could dress up \\ To get love \\ But guess what? \\ I'm never gonna be that girl \\ Who's living in a Barbie world
}

\author{
${ }^{2}$ Could wake up \\ In make up \\ And play dumb \\ Pretending that I need a boy \\ Who's gonna treat me like a toy
}

(Sit Still, Look Pretty, 2016, first and second stanza)

From the first two lines, we can catch that some women dress up to get attention from her surrounding. It is related to men stereotype that they love women from the physical appearances only. The first two line from the second stanza indicate the typical relation between women and makeup, the portrayal that women 'wake up, in make up' signifies that women are inseparable from makeups or precisely from beauty. [7] "Women's beauty serves as the foundation of women's identity and leaves them vulneable to outside approval." Therefore, some women are willing to beautify herself as beautiful as she can to expect loves or even praises from others, especially from men. Otherwise, Sit Still, Look Pretty illustrates the 'I' as a woman who is not influenced by others in interpreting beauty. The 'I' has strong desire to be a woman who defines her own beauty because she knows that she dress up to please herself, not others.

Women Are Dependent Creature. The next stereotype depicted in Sit Still, Look Pretty belongs to those who expect men to fulfill their necessity as mentioned in this stanza:

${ }^{3}$ I know the other girlies wanna wear expensive things

Like diamond rings

But I don't wanna be the puppet that you're playing on a string

This queen don't need a king

(Sit Still, Look Pretty, 2016, third stanza)

The label that women love fancy things, women spent a lot of money, women have more necessity than men are probably related to the stereotypes that women should follow the standard of beauty, thus they spend more money on beauty and fashions, as Willis (1970) had proposed that, " ... their (women) consumption is often directly related to their oppressions (e.g. makeup, soap flake) and they are special target of advertiser" [14]. Thus, Women's necessity is not cheap if compared to men. In the third stanza, Sit Still, Look Pretty divides women into 2 types in ways they fulfill their needs: those who are capable to guarantee their own necessity and those who rely on others to comply their necessity. Women dependency on 
men is program-med by the society since long time ago and still affect women in today's society. The 'I' does not directly say that it is not a good thing, but she proposes the possible negative impacts of being a dependant, for example, the men may treat them merely as an object or even as a toy that they can control. Therefore, the 'I' choose to be a working woman who is able to comply her own necessities than being a stay-at-home woman in this stanza:

\author{
${ }^{4}$ You get off on your nine to five \\ Dream of picket fences and trophy wives \\ But no, I'm never gonna be 'cause I don't wanna be \\ No, I don't wanna sit still look pretty \\ (Sit Still, Look Pretty, 2016, fourth stanza)
}

You get off on your nine to five, dream of picket fences and trophy wives means that men work from 9 a.m up to 5 p.m to reach his dreams of the ideal family's life (picket fences) and to get a trophy wife who is beautiful enough to be shown to the others. Otherwise, the 'I' refuses this notion, she does not want to be a trophy wive who is only sit still, look pretty. [7] "In order to be partners rather than servants of their husbands, wives must earn an income outside the home." Thus, it is important for women to be financially independent by taking a paid job.

Women Are the Object of Men. Beauvoir (1974) had wrote that women are defined as the opposite or deviance of men, men are the subject whereas women are the object [2]. Patriarchal system also has placed women under men's power in which men as the subject have the author-ity to control women as the object, as depicted in this stanza:

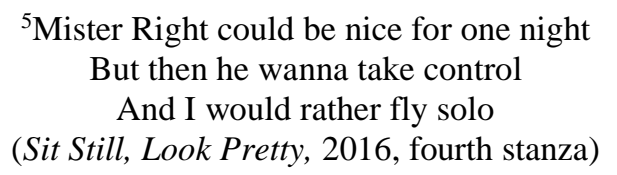

This portrayal denotes the fact that some men still control the life of her wife. Some of them do not allow his wife to determine choices, some consider his wife as a mere trophy wife. Even Mr. Right can do such repressive things to women. In general, this condition happens because women do not have financial power, as what this song portrays through the third stanza. In Fifth stanza, this song portrays that women are typically divided into two types: those who permit men to control them and those who do not allow men to reduce her as a mere object. Sit Still, Look Pretty defines the 'I' as the second type of women that are rather being solo than being controlled by men. She wants to be the subject that can control her own life. As an addition, this song also claims that 'some women even wish to be the toy of men' through a satirical way in the second stanza. By proposing this notion, this song reflects one of some feminist thoughts as Tong discuss that women need to be educated that they are not a mere object of men in her book:

"What Wollstonecraft most wanted for women is personhood ... To treat some-one as a mere means is to treat her as less than a person, as someone who exists not for herself but as an appendage to someone else. So, for example, if a husband treats his wife as no more than a pretty indoor plant, he treats her as an object that he nurtures merely as a means to his own delight. 
Similarly, if a woman lets herself so be treated, she lets herself be treated in ways that do not accord with her status as a full human person“ [7].

As a feminist anthem, Sit Still, Look Pretty certainly support the notion that women have to value themselves as a human being. Those who let men treat them as a mere object reduce their value. Though this song does not directly say that this kind of women is not empowering but it leads and triggers us to think such like that. Even though Sit Still, Look Pretty tries to promote its standpoint, the preference always depends on women themselves since feminism has grants women with the rights to determine life choice. [15] "Women's right to selfdetermination forms a core value for feminism." Self-determination is essential to uplift women's level as men.

\section{CONCLUSIONS}

Summing up the previous chapter, this song resists women stereotypes in society that are divided into 3 categories: occupational stereotypes that women are respon-sible for domestic work and not able to dream high, beauty stereotypes which include women should follow the standard of beauty and dress up to get love, personality trait stereotypes that said women are dependent and a mere object of men. This song co-vers women issues in domestic and public spheres as well as beauty stereotypes. On the other hand, the songwriters try to infuse its idea of empowered women through a working woman that has high dream, able to define her own beauty rules, dress up for self-fulfilment, financially independent and valuing herself as a subject. This portrayal flourishes within current feminist song as they try to build and transmit the stereotypes of empowered women. Even though this song tries to deliver its standpoint, the preference always depends on women. As third-wave feminists want women's preference of life choices to be women's personal picks.

\section{REFERENCES}

[1] D. Chandler, Semiotic: The basics, 2nd edition. pp. 95. London: Routledge, 2007.

[2] S, de Beauvoir, The second sex. New York: Vintage Books, 2011.

[3] L. Napikoski, "What is Feminist literary Criticism?," ThoughtCo. [Online]. Available at: https://www.thoughtco.com/feminist-literary-criticism-3528960. [Accessed: 18-Apr-2019].

[4] C. Bologna, 17 Feminist Songs That Were Ahead Of Their Time, Huffpost. [Online]. Available at: https://www.huffingtonpost.com/entry/ 17-feminist-songs-that-wereahead-of-their time_us_56fc6b46e4b0daf53 aeeaf5a. [Accessed: 12-Sep-2018]

[5] S. Fahlén, Equality at home - A question of career? Housework, norms, and policies in a European comparative perspective. Demographic Research: Vol. 35, Art 48, pp. 1411-1440, 2016.

[6] A. Park, C. Bryson, E. Clery, J. Curtice, and M. Phillips, (eds.) British Social Attitudes: the 30th Report. London: NatCen Social Research, 2013.

[7] R. Tong, Feminist thought: a more comprehensive introduction, 3rd edition. Colorado: Westview Press, 2009.

[8] K. B. Sheehan, Controversies in Contemporary Advertising, 2nd Edition. California: SAGE Publications, Inc, 2014. 
[9] M. F. Rogers, Barbie Culture: Ikon Budaya Konsumerisme. (Medhy Aginta Hidayat, Trans). Yogyakarta: Relief, 2009.

[10] Daya, Daya Breaks Down "Sit Still Look Pretty" On Genius' Video Series 'Verified,' Genius. [Online]. Available at: https://genius.com/videos/ Daya-breaksdown-sit-still-look-pretty. [Accessed: 2-June-2018].

[11] No Name, Body \& Beauty Standards on The Body Project, Bradley University. [Online]. Available at: https://www.bradley.edu/sites/body project/standards/ [Accessed: 4-Nov-2018]

[12] V. Brown, Women's body confidence becomes a 'critical issue' worldwide, Dove global study indicates, News.com.au. [Online]. Available at: https://www.news.com.au/lifestyle/beauty/face-body/womens-body-confidencebecomes-a-critical-issue-worldwide-dove-global-study-indicates/newsstory/5bf063c6a19c838cee9464a248af6bff, [Accessed: 4-Nov-2018].

[13] E. DiSalvatore, "Portrayal of Women in Advertising." [Online]. Available at: http://ellendisalvatore.weebly.com/uploads/1/1/ 9/9/11996502/research_paper_revised_women_in_adv.pdf. [Accessed: 3-Nov-2018].

[14] E. Willis, Women and the Myth of Consumerism. Ramparts, Vol. 8, No. 12, pp.1316, 1970.

[15] R. C. Snyder-Hall, Third-Wave Feminism and the Defense of "Choice." Perspective on Politics, Vol. 8, No. 1, 255-261, 2010 